\title{
Electron microscopic evidence that expression of capsular polysaccharide by Photobacterium damselae subsp. piscicida is dependent on iron availability and growth phase
}

\author{
Ana do Vale ${ }^{1, *}$, Anthony E. Ellis ${ }^{2}$, Manuel T. Silva ${ }^{1}$ \\ ${ }^{1}$ Institute for Molecular and Cell Biology, University of Porto, Rua do Campo Alegre 823, 4150-180 Porto, Portugal \\ ${ }^{2}$ Marine Laboratory, Fisheries Research Services, PO Box 101, Victoria Rd, Aberdeen AB11 9DB, Scotland, UK
}

\begin{abstract}
The expression of capsular polysaccharide (CPS) by the fish pathogen Photobacterium damselae subsp. piscicida was analysed in the virulent strain DI 21 in relation to the growth phase and presence or absence of available iron in the culture medium. Bacterial cells were processed for electron microscopy by a procedure that improves visualisation of the capsule through stabilisation with polycationic ferritin, and electron micrographs of ultrathin sections were scanned with an acquired computerised image analyser to measure capsular area. Cells grown under iron-limited conditions always had a significantly lower amount of capsular material on their surfaces than iron-supplemented cells, even when cells from different culture phases were compared. Irrespective of the presence or absence of iron in the culture medium the amount of CPS decreased with the age of the culture, i.e., from early log phase to late log phase to stationary phase. The in vivo significance of this regulatory role of iron remains to be investigated.
\end{abstract}

KEY WORDS: Photobacterium damselae - Bacterial capsule · Capsule regulation · Iron and capsular expression

Resale or republication not permitted without written consent of the publisher

Photobacterium damselae subsp. piscicida (previously Pasteurella piscicida) is the causative agent of fish pasteurellosis, a serious bacterial disease affecting different economically important marine fish species such as yellowtail, gilthead seabream, striped jack, and sea bass (Thune et al. 1993, Magariños et al. 1996a). Different studies have identified several factors/mechanisms important in the virulence of $P$. damselae subsp. piscicida (see Romalde \& Magariños 1997). Among them, the existence of efficient iron uptake systems was found to correlate with $P$. damselae subsp. piscicida pathogenicity. It has been demonstrated that this bacterium possesses a high affinity iron uptake system involving the production of both a siderophore and several ironregulated outer membrane proteins, as well as a sidero-

*E-mail: avale@ibmc.up.pt phore-independent mechanism responsible for the uptake of iron from haem-containing compounds (Magariños et al. 1994). Iron was also found to play a regulatory role in the synthesis of some proteolytic enzymes by P. damselae subsp. piscicida (Magariños et al. 1994). The presence of capsular polysaccharide (CPS) material also seems to have an important role in virulence as the presence of a capsule on $P$. damselae subsp. piscicida results in decreased levels of phagocytosis by gilthead seabream macrophages in vitro (Arijo et al. 1998). Furthermore, an increased resistance to the bactericidal action of seabream serum in vitro (Magariños et al. 1996b), as well as a reduction, by 2 to 3 log units, in the $\mathrm{LD}_{50}$ values in challenge experiments have been reported (Magariños et al. 1996b).

The expression of Photobacterium damselae subsp. piscicida CPS can be modulated by culturing the bacteria in a glucose-enriched medium (Bonet et al. 1994). Although the effect of iron as a regulator of the expression of certain virulence factors by $P$. damselae subsp. piscicida has been reported (Magariños et al. 1994), the influence of iron availability and growth phase on the CPS expression by this pathogen has not previously been addressed.

In this study, the CPS expression by a virulent strain of Photobacterium damselae subsp. piscicida, grown either under iron-limited or iron-supplemented conditions is compared. The influence of growth phase on the capsule expression by this fish pathogen was also investigated.

Materials and methods. Photobacterium damselae subsp. piscicida strain DI 21 (a virulent strain, kindly provided by Prof. Alicia Toranzo, University of Santiago de Compostela, Spain) was maintained at $-70^{\circ} \mathrm{C}$ in tryptic soy broth (TSB; Difco Laboratories, Detroit, MI, USA) supplemented with $\mathrm{NaCl}$ to a final concentration of $1 \%$ (TSB-1) and with $15 \%$ (v/v) glycerol. For the experiments, the stock bacteria were routinely cul- 
tured overnight on brain heart infusion agar (Oxoid Ltd, Basingstoke, UK) and sub-cultured in TSB-1. Ironlimited conditions were obtained by adding the iron chelator ethylenediamine-di-(O-hydroxyphenyl-acetic acid) (EDDHA; Sigma, St. Louis, MO, USA) to the TSB-1 medium at a final concentration of $100 \mu \mathrm{g} \mathrm{ml}^{-1}$. Iron-supplemented conditions were obtained by addition of $\mathrm{FeCl}_{3}(\mathrm{Fe})$ to the TSB-1 medium at a final concentration of $10 \mu \mathrm{M}$.

Cell surface fine structure of Photobacterium damselae subsp. piscicida was analysed by transmission electron microscopy of ultrathin sections by a capsule stabilisation procedure (Jacques et al. 1994), using cationised ferritin, to improve capsule visualisation. This technique has been used to visualise the capsule of $P$. damselae subsp. piscicida (Magariños et al. 1996b). Improved capsule visualisation in this bacterium by cationised ferritin probably results from the interaction between ferritin and capsular sialic acid, which is known to be present on the surface of this fish pathogen (Jung et al. 2000). The technique using cationised ferritin was applied to bacteria grown in TSB-1+EDDHA or TSB- $1+\mathrm{Fe}$ at $25^{\circ} \mathrm{C}$ in a rotary shaker at $100 \mathrm{rpm}$ and collected at the beginning (Fig. 1, a) or end (Fig. 1, b) of exponential phase and at stationary phase (Fig. 1, c). Bacteria fixed in $2.5 \%$ glutaraldehyde in cacodylate buffer (0.1 Mi pH 7.2) were allowed to react with polycationic ferritin (Sigma) at a final concentration of $1 \mathrm{mg} \mathrm{ml}^{-1}$ in the above cacodylate buffer, for $30 \mathrm{~min}$ at $25^{\circ} \mathrm{C}$ and were post-fixed in $1 \%$ osmium tetroxide in the cacodylate buffer for 3 to $4 \mathrm{~h}$. Samples were embedded in Epon 812 and thin sections were cut with an LKB Ultratome III, stained with uranyl acetate and lead citrate (Silva et al. 1987) and examined under a Zeiss EM 10C electron microscope. The experiment was repeated twice. From electron micro-

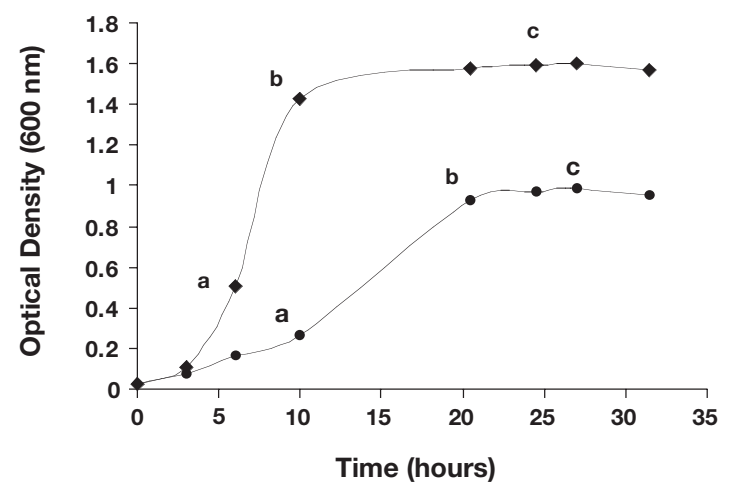

Fig. 1. Photobacterium damselae subsp. piscicida. Growth of the virulent strain DI 21 under iron-supplemented $(\bullet)$ or ironlimited conditions $(\bullet)$. Samples were collected at the beginning (a) and end (b) of exponential phase and at the stationary phase (c) and were subsequently analysed by transmission electron microscopy as described in the text scope pictures with a magnification of $36500 \times$, representative surface bacterial profiles were analysed using an acquired computerised image analyser (Leica Quantimet 500MW, Leica, Cambridge, UK). This software allowed the quantification of capsular area per length of bacterial outer membrane. Only free surface profiles in perpendicular sections were used for analysis. The results of the quantitative study described in Fig. 2 represent averages and standard deviations of 9 to 15 measurements per sample. Statistical analysis was done using Student's $t$-test.

Results and discussion. In preliminary experiments we found that a clearly visible capsule cannot be seen in Photobacterium damselae subsp. piscicida cells processed for electron microscopy using either negative staining or the conventional glutaraldehyde/osmium fixation technique for sectioned samples (not shown). It is known that, in some species, the bacterial capsule is a difficult structure to examine using conventional electron microscopic techniques. Characteristic biophysical features of bacterial capsules are their high water content and their degree of negative charge (Bayer 1990). Because the capsule is highly hydrated, the dehydration for electron microscopy often causes the capsule to collapse (Bayer et al. 1985), which is unavoidable if protective measures are not taken. Several preservation procedures have been developed to prevent structural collapse during fixation and dehydration, therefore allowing the electron microscopic visualisation of bacterial capsules (Bayer 1990). One involves the stabilisation of the capsular material by cationised ferritin, which has been used as a marker for anionic charges, and binds both to CPS and lipopolysaccharides (LPS) (Bayer 1990, Anderson 1998). Our results obtained with samples processed for ultrastructural analysis by the capsule stabilisation procedure with ferritin (Jacques et al. 1994) show that the amount of capsule on the surface of $P$. damselae subsp. piscicida cells varied, depending on both the culture conditions and growth phase (Figs. 2 \& 3). The amount of capsule covering cells was maximal on iron-supplemented bacteria collected at the beginning of the exponential phase and minimal on iron-limited cells harvested at the stationary phase. Cells grown under iron-limited conditions always had a significantly lower amount of capsular material on their surfaces than iron-supplemented cells, even when cells from different culture phases were compared. Irrespective of the presence or absence of iron in the culture medium the amount of CPS decreased with the age of the culture, i.e., from early log phase to late log phase to stationary phase. This observation indicates that studies on virulence mechanisms of bacterial pathogens should take into consideration the growth phase of the cultures. 
Fig. 2. Photobacterium damselae subsp. piscicida. Capsular polysaccharide expression by DI 21 cells grown under ironsupplemented (grey bars) or iron-limited (black bars) conditions and collected at the early exponential phase (a), late exponential phase (b) or stationary phase (c). Capsular polysaccharide expression was determined by measuring the areas of ferritin deposition around bacterial cells as described in the text. Statistical differences (Student's $t$-test) for the comparison between capsular areas were significant $(\mathrm{p}<$ 0.05 ) except for the comparison between the pair of values labelled with $*(p=0.06)$

The regulation of bacterial capsule expression is complex, involving many different factors (Costerton et al. 1981, Whitfield \& Roberts 1999). Metal availability has been reported to affect the production of some bacterial capsular exopolymers (Geesey \& Jang 1989). Iron-limited growth conditions obtained by the addition of the iron chelator 2,2-dipyridyl, deferoxamine

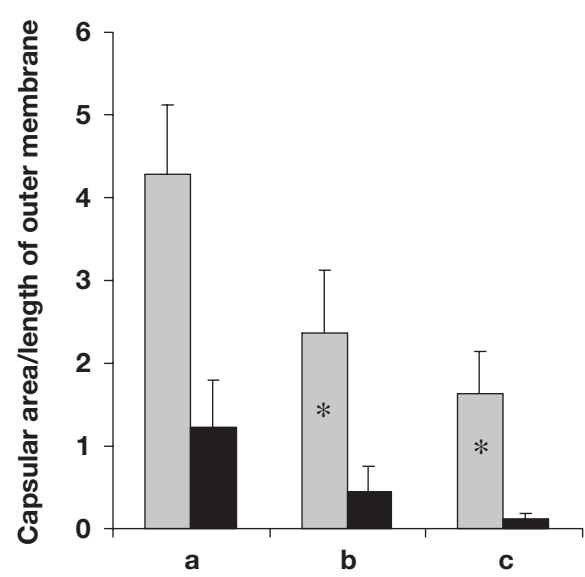

mesylate or apotransferrin to culture media have been shown to markedly reduce the amount of capsular material covering the cells of Pasteurella multocida (Jacques et al. 1994). On the other hand, the capsule of Azotobacter chroococcum appeared larger and more diffuse under iron-restricted conditions and it was suggested that such a capsule might serve to enhance iron
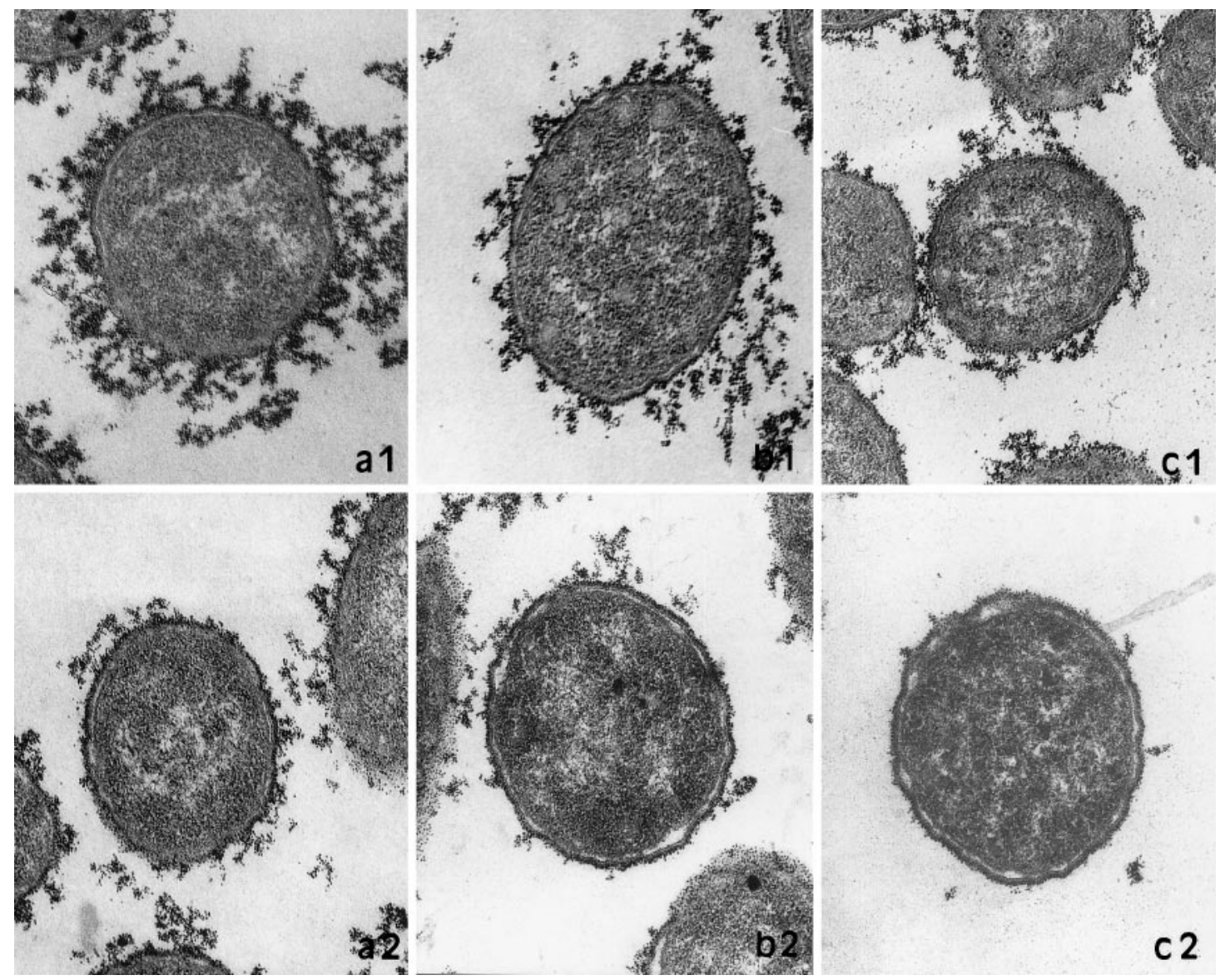

Fig. 3. Photobacterium damselae subsp. piscicida. Transmission electron micrographs of thin sections of DI 21 cells labelled with cationized ferritin. Cells were grown under iron-supplemented (a1, b1, c1) or iron-limited (a2, b2, c2) conditions and collected at the early exponential phase $(\mathrm{a} 1, \mathrm{a} 2)$, late exponential phase $(\mathrm{b} 1, \mathrm{~b} 2)$ or stationary phase $(\mathrm{c} 1, \mathrm{c} 2)$. Magnification $30000 \times$ 
sequestration under these conditions (Ferrala et al. 1986). Factors such as growth phase and growth rate were also found to influence CPS production. Wright et al. (1999) demonstrated that Vibrio vulnificus expression of CPS varied with the growth phase, being higher in the logarithmic phase than in the stationary phase. It was also documented that capsule production by $P$. multocida in broth culture was maximal during the early log phase of growth (Jacques \& Foiry 1987). Similarly, it was also proposed that cell growth rate could be a mechanism by which Streptococcus Type III CPS expression is regulated (Paoletti et al. 1996).

In conclusion, our results demonstrate that the amount of capsule in Photobacterium damselae subsp. piscicida virulent strain DI 21 varies with the age of the bacterial cultures and that iron plays a regulatory role in the CPS expression by this fish pathogen. The in vivo significance of this iron-dependent mechanism remains to be investigated.

Acknowledgements. The authors are grateful to Prof. Alicia Toranzo for providing the bacterial strain used in this study. We thank Dr Susana Lousada, Prof. Fernando Schmitt and Dr Jorge Aureliano Dias for helping with image analysis and Ms Paula M. Macedo for assistance with electron microscopy. This work was supported by a grant from the Portuguese PRAXIS XXI programme (PRAXIS XXI/BD/11038/97).

\section{LITERATURE CITED}

Anderson KL (1998) Cationized ferritin as a stain for electron microscopic observation of bacterial ultrastructure. Biotech Histochem 73:278-288

Arijo S, Borrego JJ, Zorilla I, Balebona MC, Moriñigo MA (1998) Role of the capsule of Photobacterium damsela subsp. piscicida in protection against phagocytosis and killing by gilt-head seabream (Sparus aurata, L) macrophages. Fish Shellfish Immunol 8:63-72

Bayer ME (1990) Visualization of the bacterial polysaccharide capsule. Curr Top Microbiol Immunol 150:129-157

Bayer ME, Carlemalm E, Kellenberger E (1985) Capsule of Escherichia coli K29: ultrastructural preservation and immunoelectron microscopy. J Bacteriol 162:985-991

Bonet R, Magariños B, Romalde JL, Simon-Pujol MD, Toranzo AE, Congregado F (1994) Capsular polysaccharide expressed by Pasteurella piscicida grown in vitro. FEMS Microbiol Lett 124:285-289

Editorial responsibility: David Bruno,

Aberdeen, Scotland, UK
Costerton JW, Irvin RT, Cheng KJ (1981) The bacterial glycocalyx in nature and disease. Annu Rev Microbiol 35: 299-324

Ferrala NF, Champlin AK, Fekete FA (1986) Morphological differences in the capsular polysaccharide of nitrogen-fixing Azotobacter chroococcum B-8 as a function of iron and molybdenum starvation. FEMS Microbiol Lett 33:137-142

Geesey GG, Jang L (1989) Interactions between metal ions and capsular polymers. In: Beveridge TJ, Doyle RJ (eds) Metal ions and bacteria. John Willey \& Sons, New York, p 325-358

Jacques M, Foiry B (1987) Electron microscopic visualization of capsular material of Pasteurella multocida types A and D labeled with polycationic ferritin. J Bacteriol 169: 3470-3472

Jacques M, Belanger M, Diarra MS, Dargis M, Malouin F (1994) Modulation of Pasteurella multocida capsular polysaccharide during growth under iron-restricted conditions and in vivo. Microbiology 140:263-270

Jung TS, Thompson K, Adams A (2000) Identification of sialic acid on Photobacterium damselae subspecies piscicidapossible role in cell adhesion and survival in the fish host. Fish Shellfish Immunol 10:285

Magariños B, Romalde JL, Lemos ML, Barja JL, Toranzo AE (1994) Iron uptake by Pasteurella piscicida and its role in pathogenicity for fish. Appl Environ Microbiol 60: 2990-2998

Magariños B, Toranzo AE, Romalde JL (1996a) Phenotypic and pathobiological characteristics of Pasteurella piscicida. Annu Rev Fish Dis 6:41-46

Magariños B, Bonet R, Romalde JL, Martinez MJ, Congregado F, Toranzo AE (1996b) Influence of the capsular layer on the virulence of Pasteurella piscicida for fish. Microb Pathog 21:289-297

Paoletti LC, Ross RA, Johnson KD (1996) Cell growth rate regulates expression of group B Streptococcus type III capsular polysaccharide. Infect Immun 64:1220-1226

Romalde JL, Magariños B (1997) Immunization with bacterial antigens: pasteurellosis. Dev Biol Stand 90:167-177

Silva MT, Appelberg R, Silva MNT, Macedo PM (1987) In vivo killing and degradation of Mycobacterium aurum within mouse peritoneal macrophages. Infect Immun 55: 2006-2016

Thune RL, Stanley LA, Cooper RK (1993) Pathogenesis of Gram-negative bacterial infections in warmwater fish. Annu Rev Fish Dis 3:37-38

Whitfield C, Roberts IS (1999) Structure, assembly and regulation of expression of capsules in Escherichia coli. Mol Microbiol 31:1307-1319

Wright AC, Powell JL, Tanner MK, Ensor LA, Karpas AB, Morris JG Jr, Sztein MB (1999) Differential expression of Vibrio vulnificus capsular polysaccharide. Infect Immun $67: 2250-2257$

Submitted: November 30, 2000; Accepted: January 1, 2001 Proofs received from author(s): March 13, 2001 